to the energy evinced by the waves in the particular instance under consideration.

Having learned from Lord Rayleigh that wave-action at the sea-bottom takes the form of reciprocal currents, I was let to make some experiments and observations on the formation of ripple-mark. In the course of this investigation I was soon impressed with the conviction that these altcrnate currents held at their mercy the marine fauna exposed to their attacks, and that the zoological side of the problem was at least as important as the geological. Accordingly, an outline of the subject in its zoological aspect was included in a paper on ripple-mark read to the Royal Society in I882 (Proc. R.S., vol. xxxiv. p. 1).

Having come into possession of confirmatory evidence of the action of waves at a depth of forty fathoms in the English Channel, I submitted the facts to the British Association at Southampton in the same year, r882. This paper, sent in to Section $A$, was handed on to Section $C$, a mathematical friend suggesting to me the reason, and a very good reason too, that mathematicians required no cvidence on the point contended for. However, the transfer only went to prove that the geologists were as sceptical as to the existence of wave-action at forty fathoms, as the physicists were satisfied as to that fact. This paper, amplified, appeared in the Transactions of the Devonshire Association for 1883 (vol. xv. p. 353).

The zoological aspect of the question was submitted to the British Association at Southport in 1883 ; and again to the Linnean Society in 1884 , in a paper "On the influence of wave-currents on the fauna inhabiting shallow seas." In this paper, profiting by experience, I made no attempt to prove the fact of wave-action from observation, but relied entirely on a valuable letter with which I had been favoured by Prof. Stokes, Sec.R.S. Neither at the British Association nor at the Linnean Society was any exception taken to my arguments in support of the importance of wave-action on the fauna affected ; nor, so far as I am aware, has my position been shaken since. Now that Prof. Moseley's important lecture has appcared, discussing the fauna of the sea-shore without reference to thc ever-regulating wave-currents, there is considerable risk that less experienced students of natural history will in like manner pass over this promising field of research as not worthy of their attention.

Prof. Moseley states, and states truly, that the littoral fauna is adapted in various ways to withstand "the action of the surf, the retreat of the tides, the numerous cnemies"; but, beyond the reach of surf and tidal fall, agents which only affect the narrow belt of sea contiguous to the shore, the alternate currents set up by ocean waves search out the armour and test the defences of all small animals living on those extensive marine areas, exposed to the ocean swell, where the depth of water docs not exceed fifty fathoms.

With respect to enemies, the waves themselves are perhaps the most formidable, as they attack and occasionally destroy whole colonies at once, whereas predatory foes rather affect the individual. For instance, let such helpless mollusks as Aplysia or Pleurobranchus wander over the sandy bottom of Torbay, as they sometimes do: the first easterly gale will sweep them out of existence. In fact, the waves so invariably prevent Aplysia punctata growing to its full size on the British coast, that a fullgrown specimen taken in protected Guernsey waters has been considered a distinct species-viz. A. depilans. Similar large specimens have occurred under the shelter of the Torquay harbour works, but these, by a series of odontophores and shells, I have been able to connect with the common $A$. punctata.

Prima facie it would appear that the shells of certain mollusks are more especially adapted to resist animate foes; but a close examination will often prove the contrary. Take the cases of the oyster, mussel, venus, and limpet: these mollusks are all helpless in the presence of their living enemies : the oyster perishes by the attacks of boring-sponges; the mussel is destroyed wholcsale by starfishes; the venus is perforated by carnivorous gastropods at their leisure; whilst the limpet, casily detached when taken unawares, is said to be destroyed by birds. All four are, however, admirably adapted to resist wave-currents, each in its respective habitat.

The conclusion that the shells of mollusks are so constructed as to have comparatively but little reference to living foes is supported by the interesting fact mentioned by Prof. Moseley, that hard shells tend to disappear in pelagic and deep-sea regions. That is to say, they disappear where predatory enemies abound, but where the great non-predatory cnemies, the waves, are powerless or not existent. Occasionally we find the supposed protection against living enemies to be greatly in excess of requirements-e.g. the case of the solen, whose power of burrow. ing is far greater than requisite for escape from birds, but which is none too great for the evasion of waves and currents tearing away the sand in which the mollusk dwells.

Wave-action tends to differentiatc species. This can be seen in such obvious cases as Cardium aculeatum and C. norvegicum, Venus dione and $V$. chione. One of each of these pairs has chosen the mooring method of defence with anchor-like spines, the other that of facile penetration with smooth, unresisting shell surfaces. As these two methods are opposite in action and any compromise tends to inefficiency, the wave-currents must necessarily influcnce the mollusks in the direction of divergence.

Instances of habits and forms protective arainst wave-currents could be multiplied almost ad infinitum, and, as the subject is a very interesting one, I still live in hopes that it may yet be taken up and worked out by trained observers qualified for the task.

ARTHUR R. HUNT

Torquay, September 28

\section{Prehistoric Burial-Grounds}

The account given in this week's NATURE (p. $5 \mathbf{1 8}$ ) of the discovery of a prehistoric burial-ground at Pitreavie has recalled to my memory the description of a similar find made in the eleventh or twelfth century by the monks of Noyon, and related to us us by Guibert, who was abbot of this foundation at the time. I believe that it is the earliest detailed account of any such discovery that has come down to our days; and it will be noticed that the leading features of this cemetcry are almost exactly identical with those of the Pitrcavie one. I am not aware that this passage has attracted the attention of modern writers upon prehistoric times.

Guibert, the author quoted, was born in 1053 and died in I 124, having been Abbot of Noyon for about twenty years. After stating his own conviction that his monastery was extremely old, he continues:-

"Quam opinionem, si nulla litteralis juvaret traditio, suppeteret profecto affatim peregrina, et non, putamus, Christiani nominis sepulchrorum inventa contextio. Circa enim ipsam et in ipsa basilica tantam sarcophagorum copiam conjunxit antiquitas, in multam loci famositatem tantopere expetiti, cadaverum inibi congestorum commendat infinitas. Quia enim non in morem nosirorum ordo disponitur sepulchrorum, sed circulation in modum corolle sepulchrum unius multa ambiunt, in quibus quadam reperiuntur vasa, quorum causam nesciunt Christiana tempora. Non possumus aliud credere nisi quod fuerunt gentium, aut antiquissima Christianorum, sed facta gentili more." Guiberti Novig. de Vita Sua, L. ii. cap. i.

I may add that in Guibert's time there was a very old written tradition which ascribed the foundation of Noyon to a certain "rex insulæ Britanniæ," who was (so ran the legend) a contemporary of our Lord's. This tradition is, of course, worthless from a historical point of vicw, but certainly testifies to the extreme antiquity of the place; and shows that, long before Guibert's time, the inhabitants of Noyon had dim recollections of their prehistoric greatness, which naturally, in an age of Christian credulity, centred around the era of our Lord.

I58, Walton Street, Oxford, September 30 T. A. Archer

\section{MARS, FUPITER, AND SATURN}

WITH Mars, Jupiter, and Saturn in the morning sky the telescopist has a varied assortment of brilliant objects to which he may devote his attention. The great distance of Mars during the ensuing opposition will have the effect of limiting the apparent diameter to a low value, but the chief markings are so conspicuous as to be visible notwithstanding this inimical effect. Indeed during the preceding opposition, which was equally unfavourable, some of the more delicate features appear to have been recovered. At Milan Signor Schiaparelli has partly confirmed his previous results as to the singular duplication of the "canals," and Mr. Knobel has obtained 
a series of valuable sketches, which are reproduced in the last volume of the Memoirs of the Royal Astronomical Society. With regard to Jupiter the declination of the planet will be somewhat less than during the opposition of $1884-5$, but the configuration of the belts and the peculiarities of the variable spots will doubtless continue to be exhibited with nearly similar prominence as in previous years. Saturn, situated in Gemini, and having considerable N. declination, will present a grand display, the rings being still widely open and inviting that close and systematic scrutiny which is so much needed either to affirm or negative some of the questionable details suggested by recent observations.

Observers of Mars are extremely fortunate in possessing such valuable memoirs and charts as those of Schiaparelli, Terby, Green, and others, which form a comprehensive and accurate basis of future reference and comparison. The seeming permanency of the chief lineaments on Mars and their distinctness of outline have permitted observers to assign their forms and positions with great nicety. But this has been found practically impossible in respect to any of the other planets of our system. Their markings are of so variable a tendency or so uncertain and ill-defined, owing probably to their atmospheric character, that it is out of the question to frame representative views that will serve to express the appearances observable at any future time. We have accumulated a vast number of delineations, including many peculiar forms, but these exhibit so much discordance as to prove that any attempt to arrange them with the same consistency as those of Mars must for the present be utterly futile.

What is essentially required in furtherance of our knowledge of areographic features are delineations in which the more delicate alternations of light and shade are faithfully portrayed. The ensuing opposition, though not offering the most favourable inducements for attaining this end, may yet be utilised as likely to afford its share of corroborations to old features and perhaps indicate some modification of the outlines attributed them by former observers. Mr. Marth's valuable ephemerides in the Monthly Notices supply the data wherewith the passages of certain prominent markings across the central line may be readily calculated from night to night. Drawings effected at the telescope and subsequently attested by the charts, or independent projections made on the basis of the new drawings and then compared with previous work will be important as furnishing fresh confrmations and additions to old records. Whatever plan is adopted, observers must not regard existing delineations as perfectly reliable and prejudice the judgment by endeavours to discern the outlines of the spots precisely as they have already been figured. Our work should be pursued apart from such influences, the aim being rather to correct and extend past results, than to follow them with implicit faith and mould our new seeings on the same pattern. Though much has been accomplished by the consecutive labours of the many able and earnest students of Martian features, the present state of our knowledge is not only incomplete, but considerable uncertainty exists as to the more difficult formations comprised in the physical aspect of this planet.

Jupiter, with so great a diversity of atmospheric phenomena, some of them rapidly variable, and all influenced by the quick rotation of the planet, gives prospect of being the subject of increased investigation. Late in the preceding opposition the great red spot which had so nearly disappeared and had, during the winter of 1884-5, assumed the appearance of a red ellipse with interior light cloud, showed unmistakeable evidences of increasing condensation. The ellipse grew perceptibly darker, and the central light cloud disappeared, so that at the end of the opposition the spot had almost regained the striking aspect it presented a few years ago. The question now is has this well-known feature continued to gain ascendancy during the time the planet has been lost in the sun's rays? Observations in October will furnish a definite answer to this question, and the planet should be confronted with our best telescopes as early as possible, so that the necessary evidence may be obtained. The spot will pass the central meridian of Jupiter at about the following times, and ought to be well seen in small instruments unless some great changes in an unexpected direction have affected its position or appearance in the interim since the last observation made here on the evening of July 8 :-

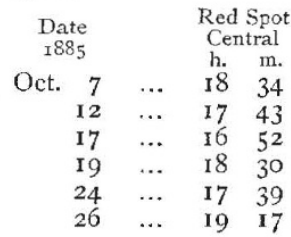

\begin{tabular}{|c|c|c|}
\hline $\begin{array}{c}\text { Date } \\
1885\end{array}$ & & $\operatorname{Rec}$ \\
\hline Oct. 29 & & I6 \\
\hline $3 I$ & $\ldots$ & r 8 \\
\hline Nov. 3 & $\ldots$ & I 5 \\
\hline 5 & $\ldots$ & I 7 \\
\hline 7 & $\ldots$ & I9 \\
\hline IO & $\ldots$ & I6 \\
\hline
\end{tabular}

With reference to the white spots bordering the dark belts, and the other definite markings, they will doubtless be remarked as heretofore. Their singular vagaries of motion and appearance call for renewed study. The varying intensity and colour of the belts and their disposition in latitude should be carefully assigned on several dates during each opposition. If this method could be persistently followed during many years it would supply the material either for tracing out periodical recurrences, or proving such changes to be intermittent in character.

During the past opposition of Jupiter much attention was directed to the transits of the satellites and their shadows. When near mid-transit, III. and IV. are often seen as black spots, I. is visible as a grey spot, while II. is rarely, if ever, visible otherwise than as a bright spot. These anomalies have never received a satisfactory explanation, and further observations are much required as to the relative tints of the satellites when on Jupiter and the variations noticeable in different transits.

Saturn, though not presenting such an extent of conspicuous detail as Jupiter, is yet equally deserving of systematic study. The rings and numerous array of satellites compensate for lack of detail in the belts. The outer division in the ring, called after Encke, supplies us with a crucial test object, and one which perhaps has originated more difference of opinion amongst observers than any other planetary detail of which the existence is well assured. Either this division must be liable to fluctuate at short intervals or the evidence afforded by various telescopes is most conflicting, and suggests how careful we should be before accepting individual results when not corroborated or supported by undeniable testimony.

During the last few oppositions a very definite narrow dark belt has bounded the southern side of the equator, and this has attracted more comment than usual owing to its compact and very obvious appearance. This belt exhibits no distinct spots, though one or two observers have delineated it with marked condensations. The fainter belts nearer the pole are so very feeble that their existence is sometimes questionable. Indeed the features of this planet are of extreme delicacy, and require not only very steady air but a thoroughly good eye and instrument to trace them in their more minute forms. Some of them are doubtless variable and have given rise to the contradictions we have referred to. As to the satellites they comprise test objects for telescopes of all calibre. The identification of these bodies may be suitably effected at any hour by means of Mr. Marth's ephemerides (Monthly Notices, June, I885).

W. F. DENNING 